\title{
Experimental model in the qualitative and quantitative assessment of non- Helicobacter gastric microflora under proton pump inhibitors action ${ }^{1}$
}

\author{
Modelo experimental na avaliação qualitativa e quantitativa da microflora gástrica não- \\ Helicobacter sob ação de inibidores de bomba de próton
}

\author{
Augusto Diogo Filho², Pablo Silva Santos ${ }^{3}$, Ânderson Silveira Duque ${ }^{3}$, Renata Cristina Cezário ${ }^{4}$, Paulo Pinto Gontijo Filho ${ }^{5}$ \\ 1. Research perfomed at Experimental Laboratory, Division of Surgical Techniques of the Surgery Department of Federal University, \\ Uberlândia Medical School (FAMED-UFU). Minas Gerais, Brazil. \\ 2. Assistant Professor, Surgery Department of FAMED-UFU. Minas Gerais, Brazil. \\ 3. Students, FAMED-UFU. Minas Gerais, Brazil. \\ 4. Fellow PhD degree, Post-Graduation Program in Applied Immunology and Parasitology of UFU. Minas Gerais, Brazil. \\ 5. Full Professor of Microbiology, Biomedical Sciences Institute of UFU. Minas Gerais, Brazil.
}

\begin{abstract}
Purpose: To evaluate models of gastric material collection from Wistar rats with and without using proton pump inhibitors(PPIs). Methods: Twenty-four rats underwent intraperitoneal omeprazol treatment, and other 12 received similar treatment with $0.9 \%$ saline. All animals underwent collection of gastric material samples, after stomach removal, by either biopsies, or aspirates, or swabs. Samples were bacteriologically processed in order to identify species and strains. Values are described as natural logarithm of colony former units per mL [ $\mathrm{Ln}(\mathrm{CFU} / \mathrm{mL})]$. Kruskal-Wallis and Mann-Whitney nonparametric tests were used, and $\mathrm{p}<0.05$ was set as statistically significant. Results: Significant difference was not seen for Ln (UFC/mL) values among the three methods of collection irrespective of using or not omeprazol. Also, significant difference was not seen in Ln (UFC/mL) values when comparing a method with each others, either using omeprazol or placebo. A significant increase of bacteria strains occurred when PPI was used, and this was seen on the three ways of collection, mainly in biopsy and swab. Conclusion: No difference occurred among the three methods of collecting bacteria samples from stomachs of rats, either when using placebo or omeprazol. A remarkable change is seen on animals bacterial microflora when PPIs are used, and bacteria are better identified when swab and biopsy are used.
\end{abstract}

Key words: Proton Pumps. Models, Animal. Rats, Wistar.

\section{RESUMO}

Objetivo: Avaliar modelos de coleta de material gástrico de ratos da linhagem Wistar, com e sem o uso de inibidores de bomba de próton (IBPs). Métodos: 24 ratos foram submetidos a tratamento com omeprazol intraperitoneal e 12 outros ratos receberam tratamento semelhante com solução salina a 0,9\%. Os animais foram submetidos a coleta de amostras de material gástrico, após retirada do estômago, utilizando-se de biópsias, aspirados ou swabs. Os materiais obtidos foram processados bacteriologicamente para identificação de espécimes quanto ao gênero. Os valores são descritos em logaritmo natural das unidades formadoras de colônias por $\mathrm{mL}$ [Ln(UFC/mL)]. Utilizou-se os testes não-paramétricos de KruskalWallis e Mann-Whitney, considerando-se p<0,05 como estatisticamente significativo. Resultados: Não se observou diferença significativa da quantidade de $\mathrm{Ln}(\mathrm{UFC} / \mathrm{mL})$ entre os três métodos de coleta, independente do uso de omeprazol. Também não se observou diferença significativa de $\mathrm{Ln}(\mathrm{UFC} / \mathrm{mL})$ ao comparar-se os métodos individualmente entre si nas condições de uso de omeprazol ou placebo. Houve aumento significativo da variedade de gêneros de bactérias com o uso de IBP, nos 3 métodos de coleta, sendo isto mais perceptível na biópsia e swab. Conclusão: Não houve diferença entre os três métodos de coleta de amostras bacterianas de estômago de ratos, tanto em uso de placebo quanto em uso de omeprazol. Nota-se uma mudança evidente da microflora bacteriana nos animais em uso de IBPs, sendo melhor identificado pelos métodos de swab e biópsia.

Descritores: Bomba de Próton. Modelos Animais. Ratos Wistar.

\section{Introduction}

Gastric juice acidity represents the first line of defence of the body against ingested bacteria ${ }^{1}$. Often, bacterial growth occurs within stomach and duodenum under conditions characterized by a decrease of gastric secretion acidity ${ }^{2}$. Intragastric $\mathrm{pH}$ increase favors the colonization by non-Helicobacter bacteria (aerobic bacteria and a lower part of anaerobic, Gram-positive and Gram-negative) ${ }^{1}$. The use of protons pump inhibitors (PPIs) is the pharmacological model of acidic suppression in the stomach, however, we have very little information on gastric and duodenal 
microflora during its use ${ }^{3}$. Recently, it is possible to see that duodenal bacterial colonization by bacteria coming from the mouth and gut are present in over a half of patients treated with proton pump inhibitors ${ }^{4}$. This is of paramount clinical importance, mainly because long-lasting treatment with these drugs may have major clinical importance, as intestinal infections ${ }^{5}$ and the formation of potentially cancerogenic compounds ${ }^{6}$. Very few experimental models are present in the literature in order that we may assess the gastric qualitative and quantitative microflora change during the use of PPIs. This way, to understand the physiopathlogy of stomach microflora changes induced by these drugs a methodological study is needed for a better gastric microbiological evaluation in order that we have a more trustful representation of this microflora. Thus, we proposed three ways for collecting gastric material, when using an animal model as to be the base of the investigation.

\section{Methods}

Thirty-six male Wistar rats, young adults, healthy, weighting $394 \pm 43.5$ g, supplied by the Experimental surgery Laboratory of the discipline Surgical Techniques of Universidade Federal de Uberlândia Medical School (FAMED-UFU). Rats were within a steel cage lined with a 35-cm lay of sawdust, kept at room temperature, with photoperiod of 12 hours (light/dark). Animals were kept in quarantine for four weeks eating a diet of clean water and dry food made of non contaminated soy bran. After weighting, they were randomly assigned to 6 groups. Into 24 animals hypochlorhydria was induced through the intraperitoneal application of omeprazol $20 \mathrm{mg} / \mathrm{kg} /$ day in the last four days of the quarantine (injectable Losar ${ }^{\circledR}$, Biochimico ${ }^{\circledR}, 1$ vial containing $4 \mathrm{mg} / \mathrm{mL}$ ). In the other rats (12) a similar way of intraperitoneal injection was performed with $5 \mathrm{~mL} / \mathrm{kg} /$ day with sterile $0.9 \%$ saline during the last four days of the quarantine. After the fourth day of applying either omeprazol or physiological solution, the animals were sacrificed, after a $(8 \mathrm{mg} / \mathrm{kg})$ ketamine anesthesia.

Surgical interventions were performed after the quarantine period, and adhering the rules of the "Guide for the case and use of laboratory animals" 7 . Before the euthanasia, the animals were examined for their general heath (mucosa appearance and physical integrity), by searching after any disease sign, and excluding from the experiment those which had abnormality. Their solid feeding was interrupted 24 hours before the surgical intervention, allowing the free use of water.

The surgical procedure was performed in the Experimental Surgery laboratory of the discipline Operatory Techniques of FAMED-UFU under strict conditions of asepsis and antisepsis. After celiotomy and stomach identification, stomach ligature was done of its proximal (esophagus) and distal (duodenum) portions, and the organ removal proceeded. Hereafter, animals were randomly assigned to one of the following:

\section{- Group 1 (8 rats + omeprazol + biopsy)}

After a wide stomach opening with lumen exposure, the organ was fixed on a sterile surgical field by its 4 ends.
Five $0.5 \mathrm{~cm}^{2}$ gastric mucosa fragments from each gastric quadrant and from its center, were collected, and these fragments were put into a tube containing $1 \mathrm{~mL}$ of nutritive medium (Tripticase Soy Broth - TSB) for culture;

- Group 2 (8 rats + omeprazol + aspirated)

With closed stomachs tied by its ends, $1 \mathrm{~mL}$ of $0.9 \%$ sterile saline was injected through sterile syringes, with immediate aspiration of $1 \mathrm{~mL}$ of gastric contents and collection into a sterile tube without culture medium;

- Group 3 (8 rats + omeprazol + swab)

Stomachs were opened and fixed on a sterile surgical field by its 4 ends, for the collection of luminal material from the gastric mucosa by swab with sterile cotton balls. This material was sowed into a tube containing $1 \mathrm{~mL}$ of TSB medium.

\section{- Group 4 (4 rats + saline + biopsy)}

In this group the injection of $0.9 \%$ saline $5 \mathrm{~mL} / \mathrm{kg} /$ day into the peritoneal cavity and gastric mucosa biopsy was performed as for Group 1.

- Group 5 (4 rats + saline + aspirated)

Similarly, $5 \mathrm{~mL} / \mathrm{kg} /$ day of $0.9 \%$ saline was injected within peritoneal cavity and $1 \mathrm{~mL}$ of the same solution into the gastric cavity after gastrectomy, with aspiration followed by $1 \mathrm{~mL}$ of gastric secretion as for Group 2 .

- Group 6 (4 rats + saline + swab)

Injection of $5 \mathrm{~mL} / \mathrm{kg} /$ day saline into the peritoneal cavity and collection of gastric material from the gastric mucosa by swab, as for Group 3.

After the collection, suitably labeled tubes containing samples were immediately transported to the Microbiology Laboratory of Biomedical Sciences Institute of UFU.

\section{Culture}

Samples collected were diluted within $0.9 \%$ saline at the proportions of 1:10, 1:100 and 1:1000. $0.1 \mathrm{~mL}$ of diluted material was aspired and spread over agar McConkey and agar Manitol-salt plates for each dilution by Drigalski loop. Agar plates were put into a heater at $37^{\circ} \mathrm{C}$ for $24-48$ hours. After this time period, colonies obtained from each stomach were counted by their colonies forming units per milliliter (CFU/mL). The study purpose was the analysis of aerobic bacteria. In case of doubt in terms of identification, we used Gram dyeing and microscopic analysis. Then, colonies identified were inoculated into favorable media which were the most suitable for their strains, according to the "Color atlas and textbook of diagnostic microbiology” ${ }^{8}$.

\section{Statistical analysis}

Results are presented as unit value or as a mean with the respective standard deviation (SD) and expressed as natural logarithm $[\mathrm{Ln}(\mathrm{CFU} / \mathrm{mL})]$. The amount of bacteria was quantified by counting colonies former units (CFU), identified in agar medium. Non-parametric Kruskal-Wallis 
tests were used for multiple comparisons and the MannWhitney test for comparing 2 samples, and values were set as significant when $\mathrm{p}<0.05$. Only samples whose bacterial growth was higher than zero were used in the statistical analysis.

\section{Results}

Tables 1 to 3 show the amount of bacteria in Ln(CFU/ $\mathrm{mL}$ ) for each collection method used in the study. The average amount of bacteria in rats which undergone omeprazol treatment was $9.02 \pm 6.85 \mathrm{Ln}(\mathrm{CFU} / \mathrm{mL})$ in aspirated, 9.57 $\pm 2.16 \mathrm{Ln}(\mathrm{CFU} / \mathrm{mL})$ in biopsy and $10.53 \pm 3.77 \mathrm{Ln}(\mathrm{CFU} /$ $\mathrm{mL}$ ) in swab. There was not statistical difference among the three methods of gastric collection (Figure 1). Means of values seen in animals receiving placebo were $(6.57 \pm 1.36$ $\mathrm{Ln}(\mathrm{CFU} / \mathrm{mL})$ in the aspirated, $7.32 \pm 1.69 \mathrm{Ln}(\mathrm{CFU} / \mathrm{mL})$ in the biopsy and $8.83 \pm 1.34 \mathrm{Ln}(\mathrm{CFU} / \mathrm{mL})$ in the swab). Also, there was not statistical difference between the 3 methods with the use of placebo (Figure 1). When comparing samples of each method with each other, with or without using omeprazol no significant difference was seen in the bacteria amount (Tables 1 to 3 ). Tables 4 to 6 show a variety of bacteria strains $[\mathrm{Ln}(\mathrm{CFU} / \mathrm{mL})]$, isolated for each one of the collection methods used, with or without using omeprazol. Results expressed as unit values represent bacteria which did not repeat in the samples collected, and values presented as means with their respective standard deviations were for those bacteria which repeated in the samples collected. Irrespectively the collection technique used Staphylococcus ssp. were always seen. There is a remarkable qualitative difference among the gastric microflora of non-Helicobacter aerobic bacteria if we compare the variety of strains isolated after using omeprazol and placebo. It is possible to see that in animals receiving omeprazol when compared to the ones receiving placebo, the quality of gastric microflora shows significant changes, and it is possible to identify bacterial strains which are different from those obtained without PPI. We may consider that all bacteria seen when using omeprazol are also identified in the placebo group, excepting one of the samples, treated with placebo, with collection by aspiration, where Corynebacterium ssp. were seen.

TABLE 2 - Quantity of bacteria [Ln(UFC/mL)] obtained in each sample by biopsy tecnique after administration of omeprazol/placebo.

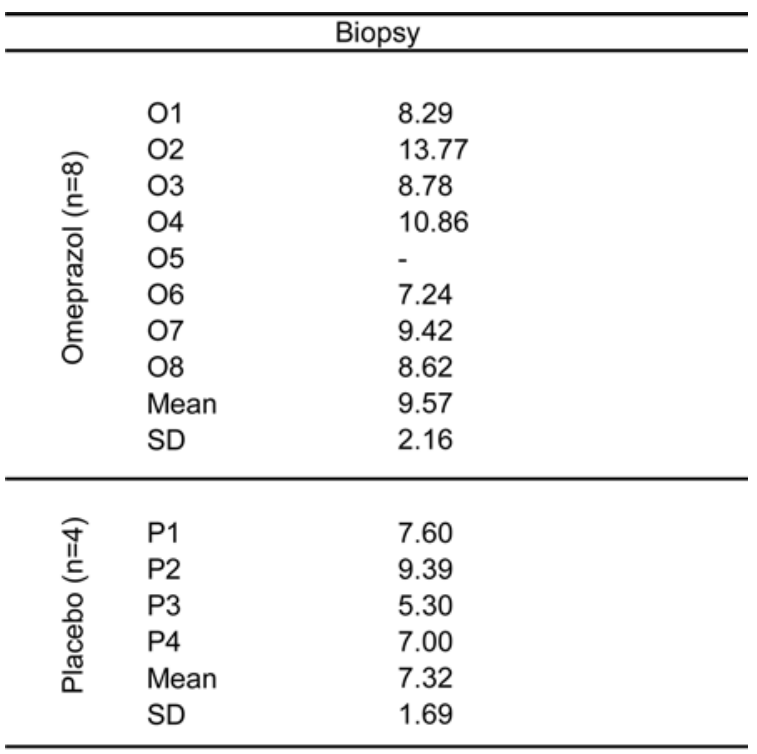

(-) without bacteria growth

Mann-Whitney test, $p=0.2345$
TABLE 1 - Quantity of bacteria [Ln(UFC/mL)] obtained in each sample by aspiration tecnique after administration of omeprazol/placebo.

\begin{tabular}{|c|c|c|}
\hline \multicolumn{3}{|c|}{ Aspirated } \\
\hline 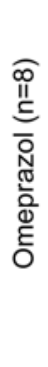 & $\begin{array}{l}\text { O1 } \\
\text { O2 } \\
\text { O3 } \\
\text { O4 } \\
\text { O5 } \\
\text { O6 } \\
\text { O7 } \\
\text { O8 } \\
\text { Mean } \\
\text { SD }\end{array}$ & $\begin{array}{l}17.25 \\
4.61 \\
- \\
- \\
11.92 \\
- \\
- \\
2.30 \\
9.02 \\
6.85\end{array}$ \\
\hline 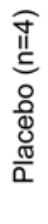 & $\begin{array}{l}\text { P1 } \\
\text { P2 } \\
\text { P3 } \\
\text { P4 } \\
\text { Mean } \\
\text { SD }\end{array}$ & $\begin{array}{l}8.01 \\
6.41 \\
5.30 \\
- \\
6.57 \\
1.36\end{array}$ \\
\hline
\end{tabular}

(-) without bacteria growth

Mann-Whitney test, $p=0.4969$
TABLE 3 - Quantity of bacteria [Ln(UFC/mL)] obtained in each sample by swab tecnique after administration of omeprazol/placebo.

\begin{tabular}{|c|c|c|}
\hline \multicolumn{3}{|c|}{ Swab } \\
\hline 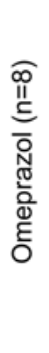 & $\begin{array}{l}\text { O1 } \\
\text { O2 } \\
\text { O3 } \\
\text { O4 } \\
\text { O5 } \\
\text { O6 } \\
\text { O7 } \\
\text { O8 } \\
\text { Mean } \\
\text { SD }\end{array}$ & $\begin{array}{l}12.60 \\
16.25 \\
10.13 \\
6.68 \\
13.73 \\
- \\
7.60 \\
6.73 \\
10.53 \\
3.77\end{array}$ \\
\hline 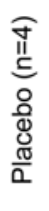 & $\begin{array}{l}\text { P1 } \\
\text { P2 } \\
\text { P3 } \\
\text { P4 } \\
\text { Mean } \\
\text { SD }\end{array}$ & $\begin{array}{l}10.31 \\
8.52 \\
7.68 \\
- \\
8.83 \\
1.34\end{array}$ \\
\hline
\end{tabular}

(-) without bacteria growth

Mann-Whitney test, $\mathrm{p}=0.6711$ 


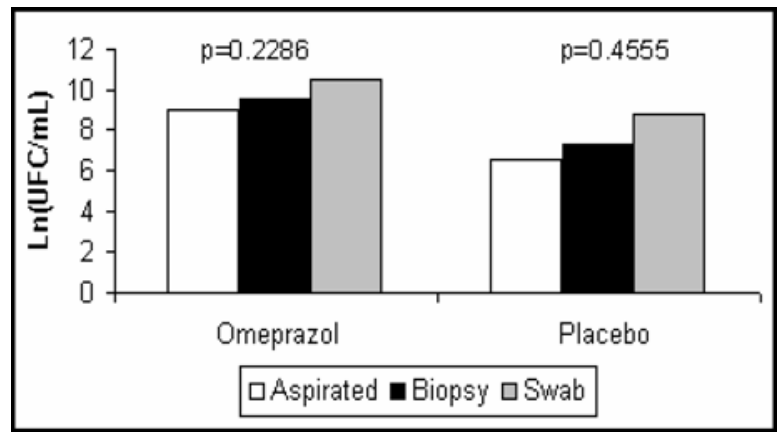

FIGURE 1 - Amount of bacteria [Ln(UFC/ml)] according to each collection method after using omeprazol/ placebo (Kruskal-Wallis test).

TABLE 4 - Bacteria strain [Ln(UFC/ml)] (mean \pm SD or unit value) obtained by aspíration after administration of omeprazol/placebo.

\begin{tabular}{|c|c|}
\hline Aspirated & \\
\hline 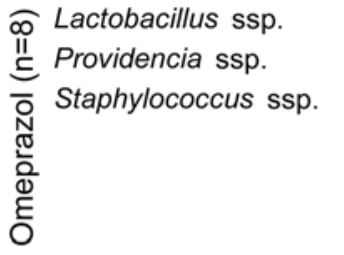 & $\begin{array}{l}4.90 \\
7.28 \\
3.23 \pm 3.30\end{array}$ \\
\hline 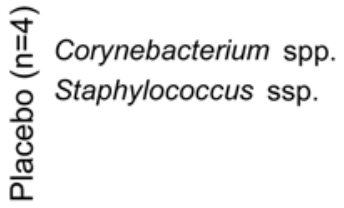 & $\begin{array}{l}3.00 \\
2.53 \pm 0.83\end{array}$ \\
\hline
\end{tabular}

TABLE 5 - Bacteria strain [Ln(UFC/ml)] (mean \pm SD or unit value) obtained by biopsy after administration of omeprazol/placebo.

\begin{tabular}{|c|c|}
\hline \multicolumn{2}{|l|}{ Biopsy } \\
\hline GNNFR* $^{*}$ & 2.78 \\
\hline Budvicia ssp. & 2.00 \\
\hline II Citrobacter ssp. & $3.85 \pm 1.20$ \\
\hline$\stackrel{\subseteq}{-}$ Corynebacterium ssp. & $3.92 \pm 1.30$ \\
\hline Nิ Edwarsiella ssp. & 3.00 \\
\hline 는 Listeria ssp. & $3.85 \pm 1.20$ \\
\hline$\stackrel{\oplus}{E}$ Proteus spp. & $2.23 \pm 0.42$ \\
\hline Staphylococcus ssp. & $3.48 \pm 1.07$ \\
\hline \multirow{3}{*}{ 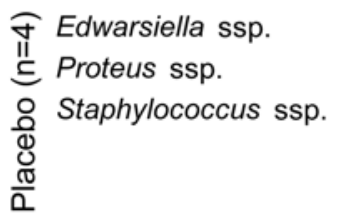 } & 4.04 \\
\hline & 3.00 \\
\hline & $3.54 \pm 0.76$ \\
\hline
\end{tabular}

$\left({ }^{*}\right)$ Gram negative non-ferment rod
TABLE 6 - Bacteria strain [Ln(UFC/ml)] (mean \pm SD or unit value) obtained by swab after administration of omeprazol/placebo.

\begin{tabular}{|c|c|}
\hline Swab & \\
\hline 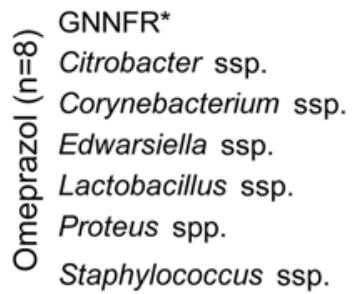 & $\begin{array}{l}2.00 \\
5.75 \\
4.91 \pm 1.65 \\
3.48 \\
3.00 \\
3.68 \pm 2.93 \\
3.81 \pm 1.56\end{array}$ \\
\hline 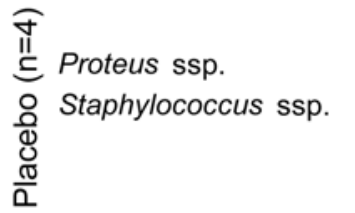 & $\begin{array}{l}2.21 \pm 0.29 \\
3.12 \pm 0.7\end{array}$ \\
\hline
\end{tabular}

$\left({ }^{\star}\right)$ Gram negative non-ferment rod

\section{Discussion}

The effect of acidic secretion on bacterial flora is widely discussed in the scientific literature. In several classic studies the importance of gastric juice acidity as the mechanism of microbiological control ${ }^{9,10}$. Gianella et al. ${ }^{9}$ highlight the importance of the gastric juice as the first line of defense against ingested bacteria, proposing that in a $\mathrm{pH}$ under 4, 99.9\% of ingested bacteria are died after a 30minut exposition to gastric juice. By frequently using drugs which induce hypochlorhydria, harms and consequences are possible when this type of natural protection is annulled. Wilder-Smith et al. ${ }^{11}$ described that a $\mathrm{pH}$ under 4 has clear bactericide effect and a pH over 4 makes the stomach viable for bacterial colonization. The importance of detecting nonHelicobacter flora has been seen in several trials dealing with hypochlorohydria. Sanduleanu and coworkers ${ }^{12}$ report that in individuals with Helicobacter pylori the association of non-Helicobacter flora speeds the development of gastric body atrophic gastritis. Gossens and coworkers, in a study assessing the viability of Lactobacillus plantarum in fecal material of 29 volunteers with either placebo or pantoprazol (proton pump inhibitor) showed that there was not interference when using pantoprazol in the amount of aerobic bacteria isolated ${ }^{12}$. In our study, from the assumption of medicinal hypochlorohydria influence on the gastric microflora as an allowing factor for bacterial proliferation, it is possible to observe that no significant difference of CFU/ $\mathrm{mL}$ number in the quantitative analysis between the stomach with acidic secretion preserved and hypochlorhydria stomach. By understanding the interrelationship between gastric microflora and changes induced by drugs which inhibit gastric secretion (PPIs, antagonists of receptor H2, etc.), the need of a standardization of the way to collect gastric samples becomes relevant to evaluate bacterial microflora in rats. In several studies biopsies or aspirated are used for detecting the stomach microflora, however, 
without worrying about showing which would be the most accurate method for this ${ }^{13,14}$. Sanduleanu et al. ${ }^{16}$ in a series of 220 patients with dyspeptic disease under continuous use of proton pump inhibitors or an antagonist of the receptor $\mathrm{H} 2$, undergone to endoscopy with juice collection and gastric juice and biopsy, showed that patients using IBPs have higher prevalence of non- $H$. pylori flora than the control group both in gastric aspirated and biopsy. In the above study, even with microbiological investigation, there was not concern about describing which would be the most accurate way of collection ${ }^{15}$. In terms of the suitable technique of performing the collection, we did not see any difference among the three methods studied for quantifying non-Helicobacter flora. In our study it was not possible to show difference in the amount of bacteria isolated in the three methods of collection either with placebo or omeprazol, however it is important to highlight that in 50\% of samples treated with omeprazol where the aspiration technique was used, bacterial growth did not occur which perhaps may be explained for some factors inherent to the collection technique, as immediate aspiration of gastric juice, or the use of saline with the transportation mean. This, however, did not interfere with the statistical analysis. It is well documented that the dominant flora in the rat stomach is constituted by Lactobacillus ssp. and Staphylococcus ssp. ${ }^{16}$. Kawai and Suegara ${ }^{18}$ when evaluating gastric flora in rats concluded that Staphylococcus ssp. predominate in the keratinized region of the stomach, but they disappear after the inoculation of Lactobacillus ssp. In our study, it was possible to show in omeprazol non-treated rats, a predominance of Staphylococcus ssp., irrespectively the technique used. The study of hypochlorohydria action on the gastric flora is clearly showed by the significant change of the microbiological pattern seen in animals treated with PPIs. When Zavros et al. ${ }^{19}$ studied the relationship between hypochlorohydria and gastritis in rats without gastrine expression or using omeprazol they saw a consistent increase of the non-Helicobacter flora associated with a major inflammation in that models. Our findings showed a predominance of Staphylococcus ssp., besides Corynebacterium ssp., Citrobacter ssp. and Listeria ssp. Other species could also be identified as non-fermenting Gram negative rods and Budvicia ssp. Zavros et al.observed a predominance of Lactobacillus ssp., Enterobacter cloacae, Staphylococcus ssp., and Proprionibacterium ssp. in rats undergone to hypochlorohydria for 8 weeks with a $400 \mathrm{ìmol} / \mathrm{kg} /$ day omeprazol dose ${ }^{18}$. It is important to see that in spite of the difference of specimes the change of the microflora is a verifiable phenomenon. Perhaps the difference could be explained by the difference of dosage and time of treatment with the mentioned drug. In our findings, another remarkable aspect and not described in other studies ${ }^{20,21}$ is that, in spite of quantitatively swab, aspirated and biopsy do not significantly differ, the variety of bacteria obtained by swab and biopsy make them better ways for qualitative evaluation than the aspirated since through the aspirated only 2 strains of bacteria were obtained while 7 different species were obtained with swab and 8 with biopsy.

\section{Conclusion}

No difference occurred among the three methods of bacterial samples collection from rat stomachs, by using both placebo and omeprazol. A clear change was seen in bacterial microflora in animals using PPIs, being better identified by the methods swab and biopsy.

\section{References}

1. Thorens J, Froehlich F, Schwizer W, Saraga E, Bille J, Gyr K, Duroux P, Nicolet M, Pignatelli B, Blum AL, Gonvers JJ, Fried M. Bacterial overgrowth during treatment with omeprazole compared with cimetidine: a prospective randomised double blind study. Gut. 1996;39(1):54-9.

2. Howden CW, Hunt RH. The relationship between gastric secretion and infection. Gut. 1987;28:96-107.

3. Saltzman JR, Kowdley KV, Pedrosa MC, Sepe T, Golner B, Perrone G, Russell RM. Bacterial overgrowth without clinical malabsorption in elderly hypochlorhydric subjects. Gastroenterology. 1994;106:615-23.

4. Fried M, Siegrist H, Frei R, Froehlich F, Duroux P, Thorens J. Duodenal bacterial overgrowth during treatment in outpatients with omeprazole. Gut. 1994;35:23-6.

5. Wingate DL. Acid reduction and recurrent enteritis. Lancet. 1990; i:222.

6. Reed PI, Haines K, Smith PLR, House FR, Walters CL. Gastric juice $\mathrm{N}$-nitrosamines in health and gastroduodenal disease. Lancet. 1981; ii: 550-2.

7. Clark JD. Guide for the care and use of laboratory animals. Institute of laboratory animal research, Comission Life Sciencies, National Research Council. Washington DC: National Academy Press; 1996.

8. Koneman EW, Allen SD, Dowell Jr VR, Sommers HM. Diagnóstico microbiológico: texto e atlas colorido. 2.ed. São Paulo: Panamericana; 1993.

9. Gianella RA, Broitman SA, Zamcheck N. Gastric acid barrier to ingested microorganisms in man: studies in vivo and in vitro. Gut. 1972;13:251-6.

10. Howden CW, Hunt RH. Relationship between gastric secretion and infection (progress report). Gut. 1987; 28: 96-107.

11. Wilder-Smith CH, Spirig C, Krech T, Merki HS. Bactericidal factors in gastric juice. Eur J Gastroenterol Hepatol. 1992; 4: 885-91.

12. Sanduleanu S, Jonkers D, de Bruine A. Double gastric infection with Helicobacter pylori and nonHelicobacter pylori bacteria enhances the expression of circulating pro-inflammatory cytokines and parallels the development of atrophic corpus gastritis. Gut. 2000; 47(Suppl. III): A110.

13. Goossens D, Jonkers D, Russel M, Thijs A, van den Bogaard A, Stobberingh E, Stockbrügger R. Survival of the probiotic, $L$. plantarum $299 \mathrm{v}$ and its effects on the faecal bacterial flora, with and without gastric inhibition. Dig Liver Dis. 2005; 37:44-50. 
14. Brummer, R. J.; Stockbrügger, R. W. Effect of nizatidine $300 \mathrm{mg}$ at night and omeprazole $20 \mathrm{mg}$ in the morning on 24-hour intragastric $\mathrm{pH}$ and bacterial overgrowth in the patients with acute duodenal ulcer. Dig Dis Sci. 1996; 41: 2048-54.

15. Carvalho LR, Farias LM Nicoli JR, Silva MCF, Corsino ATSM, Lima LA, Redondo RAF, Ferreira, PCP, Pinto MEBM. Dominant culturable bacterial microbiota in the digestive tract of the american black vulture (Coragyps atratus Bechstein 1793) and search for antagonistic substances. Braz J Microbiol. 2003; 34: 218-24.

16. Sanduleanu S, Jonkers D, de Bruine A, Hameeteman W, Stockbrügger, RW. Non-Helicobacter pylori bacterial flora during acid-supressive therapy: diferential findings in the gastric juice and gastric mucosa. Aliment Pharmacol Ther. 2001, 15:379-88.

17. Suegara N, Morotomi M, Watanabe T, Kawal Y, Mutai M. Behavior of microflora in the rat stomach: adhesion of lactobacilli to the keratinized epithelial cells of the rat stomach in vitro. Infect Immunol. 1975: 12(1): 173-9.

18. Kawai Y, Suegara N. Specific adhesion of lactobacilli to keratinized epithelial cells of the rat stomach in vitro. Am J Clin Nutr. 1977: 30:1777-80.
19. Zavros Y, Rieder G, Fergunson A, Samuelson LC, Merchant JL. Genetic or chemical hypochlorhydria is associated with inflammation that modutates parietal and G-cell populations in mice. Gastroenterology. 2002: 122:119-33.

20. Viani F, Siegrist HH, Pignatelli B, Cederberg C, Idstrom JP, Verdu EF, Fied M, Blum AL, Armstrong D. The effect of intra-gastric acidity and flora on the concentration of $\mathrm{N}$-nitroso compounds in the stomach. Eur J Gastroenterol Hepatol. 2000;12:165-73.

21. Mowat C, Williams C, Gillen D, Hossack M, Gilmour D, Carswell A, Wirz A, Preston T, McColl KE. Omeprazole, Helicobacter pylori status, and alterations in the intragastric milieu facilitating bacterial N-nitrosation. Gastroenterology. 2000;119:339-47.

\section{Acknowledgement}

To Claudete Freitas of Microbiology Laboratory of UFU, for her help, collaboration, and availability for this work.

\section{Correspondence:}

Augusto Diogo Filho

Av. Levino de Souza, 1775

38405-322 Uberlândia - MG Brazil

Phone: (5534)3218-2181/9971-7286

diogofilho@netsite.com.br
Conflict of interest: none Financial source: Funding: Hospital de Clínicas-UFU and FAPEMIG

Received: April 09, 2006

Review: May 10, 2006

Accepted: June 13, 2006

\section{How to cite this article:}

Diogo Filho A, Santos PS, Duque AS, Cezário RC, Gontijo Filho PP. Experimental model in the qualitative and quantitative assessment of non-Helicobacter gastric microflora under proton pump inhibitors action. Acta Cir Bras. [serial on the Internet] 2006 Sept-Oct;21(5). Available from URL: http://www.scielo.br/acb. 